Original Research Paper

\title{
Important Factors in Information Technology Governance Awareness: An Empirical Survey of the Expert's Opinion in Indonesia
}

\author{
Bobby AA Nazief, Uky Yudatama and Achmad Nizar Hidayanto \\ Department of Computer Science, Universitas Indonesia, Indonesia
}

\author{
Article history \\ Received: 14-04-2019 \\ Revised: 25-07-2019 \\ Accepted: 01-08-2019 \\ Corresponding Author: \\ Uky Yudatama \\ Department of Computer \\ Science, Universitas Indonesia, \\ Indonesia \\ Email: uky.yudatama@ui.ac.id
}

\begin{abstract}
Information Technology Governance (IT Governance) implementation does not always experience success in an organization. This article has provided data by conducting a survey to experts, in this case, the IT Governance Expert in Indonesia to be asked for their opinions regarding the successful implementation of IT Governance in supporting the organization's routine activities. This research report is presented precisely and concisely by displaying tables and pie diagrams so that it is easy to understand. Responses obtained from IT Governance Expert perceptions, that awareness is an important factor that can determine success in the implementation of IT Governance. We found as many as 15 factors in IT Governance awareness. In addition, a very significant part of the result findings of this research is awareness to understanding IT Governance well, awareness in involving stakeholders and awareness in changing organizational culture. Therefore, it needs to have serious attention from all parties involved so that later organizational performance can be increased in the future in accordance with expectations.
\end{abstract}

Keywords: Information Technology Governance, Awareness, Survey,

Expert

\section{Introduction}

Information Technology Governance (IT Governance) is the responsibility of the board of directors and executive management. It is an integral part of enterprise governance and consists of the leadership and organizational structures and processes to ensure that the organization sustains and extends its strategy and objectives, but not all IT governance implementations can be successful (Aoun et al., 2011). This failure in implementation may have a negative impact on the survival of an organization (Ali and Green, 2012; De Haes et al., 2017), the most felt impact is mainly related to a decrease in credibility and trust in the company (Hardy, 2006; Van Grembergen, 2006) worse is that it can result in company closure (Yudatama and Sarno, 2015). Of course, this is very undesirable. Various efforts have been made, especially by top management by always exercising control and supervision over the implementation of IT Governance (Hardy, 2006; Alreemy et al., 2016; Bianchi and Sousa, 2016; Yang et al., 2012; De Haes and Van Grembergen, 2008), but this seems insufficient because they still have not received the results according to what is expected.

Governance with management has different meanings. The difference is that Governance focuses on supervision, accountability and strategic decisions, while management focuses on strategic decisions, management decisions and operational management. The Intersection between Governance with management is in the area of strategic decisions. Governance has an upper middle coverage area while management covers the middle to lower areas. From this explanation, the coverage area of Governance is the ranks of the board of directors while the scope for management is level management down.

Implementation of IT Governance involves all components in a company (Yang et al., 2012; De Haes and Van Grembergen, 2008; Xiang et al., 2014), where one component and the other work together, interrelated and influence each other (Al Qassimi and Rusu, 2015; Altemimi and Zakaria, 2016; Lee et al., 2008). People are one of the most important components (Yadav and Barve, 2015), where people have unique and unpredictable characteristics (Da Veiga and Eloff, 2007; 
Yadav and Barve, 2015; Kuusk and Gao, 2015). Humans are a very important part of having knowledge, attitudes and behaviors in psychology, often called Awareness (Ishak and Zabil, 2012; Desa et al., 2011).

In this study, we want to investigate the factors that cause failure or success in the implementation of IT Governance related to human behavior, where researchers in the field of IT Governance have never discussed it. Therefore, this is a new breakthrough step.

In this paper presents the results of a survey that has been carried out by involving experts in the field of IT Governance in Indonesia relating to their opinions, namely on important matters that can influence the success of IT Governance implementation in supporting routine activities organizational. Where in this paper, starting with an introduction containing the background of the research conducted, then continues with the literature which is a supporter in this study, followed by the research method as the direction and stages of work. After discussing the research methodology, then discuss the results and discussion. The final section concludes with conclusions and future research by providing suggestions and input for future research.

Expectations from the final results of this study can provide information about the importance of IT governance awareness and find important factors in awareness so that it is expected to support the successful implementation of IT Governance in an organization.

\section{Literatur Relevan}

Relevant research related to IT Governance awareness has been carried out by ISACA 2013 by surveying 843 IT professionals in the Asia Pacific region. The results of the study state that increasing awareness among employees is considered as the most important action to improve IT risk management which is one of the objectives of IT Governance (Teo et al., 2013). Another relevant research is done in Indonesia namely discussing awareness by referring to and considering benefits, risk reduction, opportunities and obstacles (Yudatama et al., 2017), which later this research was developed with using Interpretive Structural Model (ISM) to look for the hierarchical relationship of each of these factors (Yudatama et al., 2018a). In addition, there are studies that explore and provide recommendations on the priority scale of the elements in the document on IT resources related to awareness in the implementation of IT Governance (Yudatama et al., 2018b).

\section{Methodology Research}

This research is exploratory research, not experiment, where we want to explore the opinions of experts with regard to any important factors, which are contained in the awareness that can influence success in the implementation of IT Governance. Our data is collected through surveys with direct interviews with experts.

In this study, it begins with collecting data. Data is obtained by involving experts whose criteria have been determined by considering the level of education and experience in the field of IT Governance spread across several major cities in Indonesia, namely Jakarta-DKI, Depok-West Java, Bandung-West Java, SemarangCentral Java and Yogyakarta-DIY.

An expert is someone who has knowledge, experience, abilities and skills in his field that has been proven by the results of his work and credibility recognized by others. These experts have the knowledge, experience and ability so that they can provide input related to information that is important in this study.

The basis for determining and selecting experts involved in this research, namely by paying attention to the profile of the expert. The profiles of the experts involved in this study all have experience of working for more than 10 years, with an educational background in Computer Science in the field of IT Governance, at least having a master's degree.

To get accurate information, at least involving 3 experts who are competent in their field (Usta, 2019). We do not only involve 3 experts, but we have involved as many as 20 experts who are competent in the field of IT Governance spread across Indonesia, with the consideration that the more experts are involved, the better and more accurate results will be obtained.

In this study, we have determined the number of experts as many as 20 , which we then visit one by one to request opinions from them regarding the implementation of IT Governance. We have prepared questions beforehand to be given to experts. All experts answered the questions we gave to him. The answers from all experts, we process all without exception, because we are sure that all answers from experts are valid.

Questionnaire questions have been carefully prepared, brief and solid especially those related to the implementation of IT Governance so the results are expected to be unbiased but clear. The focus of the question is directed at the success and failure of the implementation of IT Governance in an organization, then it is associated with a position of awareness about its important role and what factors are contained in that awareness.

These 20 experts, answered all the questions we gave to him. Answers from all experts, we process all without exception because we are sure that all answers from experts are valid. After we get answers from experts through surveys, we then process the data using software Mat Lab Ver. 5.0. We deliberately use this software, because it is more flexible, that is, it can process numerical data and at the same time can display images from the processed data. 


\section{Results and Discussion}

Table 1 illustrates the demographics of respondents involving a number of experts who are competent in the field of IT Governance spread across several major cities in Indonesia. This expert is chosen based on reliable ability both in his experience and knowledge.

With a balanced composition between 50\% practitioners and $50 \%$ academics, it is expected to provide high-quality results. The interesting thing about the demographics of respondents is gender-related, namely the number of experts among female is not as much as the number of male experts, this is understandable because in Indonesia there are not many females who hold strategic positions in an organization and few of them are involved in the IT Governance, but this does not significantly affect the quality of this research. As stated earlier that in this study, the selected experts had high criteria and qualifications with more than 11 years experience working in their fields as much as $80 \%$ and having magister and doctoral education with a total of $80 \%$.

Table 2 is data that displays the list of questions along with answers from respondents who have been processed using statistical software. To be able to provide a clearer understanding of Table 2, have been shown images in the form of pie charts of each question and answers from respondent's.

Table 1: Demographics from IT governance expert in Indonesia

\begin{tabular}{llcr}
\hline Variable & Characteristics & Frequency & Percentage \\
\hline Gender & Male & 18 & 90 \\
& Female & 2 & 10 \\
Position & Practitioner & 10 & 50 \\
& Academics & 10 & 50 \\
Graduated & Bachelor & 4 & 20 \\
& Master & 7 & 35 \\
Experience & Doctor & 9 & 45 \\
& $<=5$ Years & 1 & 5 \\
& 6-10 Years & 3 & 15 \\
& $11-15$ Years & 6 & 30 \\
& $16-20$ Years & 0 & 0 \\
\end{tabular}

Table 2: Survey result from IT Governance expert in Indonesia

\begin{tabular}{|c|c|c|c|c|c|c|}
\hline \multirow{2}{*}{$\frac{\text { No }}{1 .}$} & \multicolumn{3}{|l|}{ Questions } & \multicolumn{3}{|l|}{ Answers } \\
\hline & $\begin{array}{l}\text { How important is the role of IT Governance } \\
\text { in supporting organizational activities? }\end{array}$ & $\begin{array}{l}\text { Very } \\
\text { Important } \\
18(90 \%)\end{array}$ & $\begin{array}{l}\text { Important } \\
1(5 \%)\end{array}$ & $\begin{array}{l}\text { Undecided } \\
1(5 \%)\end{array}$ & $\begin{array}{l}\text { Not } \\
\text { Important } \\
0(0 \%)\end{array}$ & $\begin{array}{l}\text { Very } \\
\text { Unimportant } \\
0(0 \%)\end{array}$ \\
\hline 2. & $\begin{array}{l}\text { Is the implementation of IT Governance } \\
\text { always experiencing success as expected? }\end{array}$ & $\begin{array}{l}\text { Strongly } \\
\text { Agree } 1(10 \%)\end{array}$ & $\begin{array}{l}\text { Agree } \\
4(20 \%)\end{array}$ & $\begin{array}{l}\text { Undecided } \\
2(10 \%)\end{array}$ & $\begin{array}{l}\text { Disagree } \\
11(55 \%)\end{array}$ & $\begin{array}{l}\text { Strongly } \\
\text { Disagree } 1(5 \%)\end{array}$ \\
\hline 3. & $\begin{array}{l}\text { Can the implementation of IT Governance } \\
\text { experience a failure? }\end{array}$ & $\begin{array}{l}\text { Strongly } \\
\text { Agree4 }(20 \%)\end{array}$ & $\begin{array}{l}\text { Agree } \\
16(80 \%)\end{array}$ & $\begin{array}{l}\text { Undecided } \\
0(0 \%)\end{array}$ & $\begin{array}{l}\text { Disagree } \\
0(0 \%)\end{array}$ & $\begin{array}{l}\text { Strongly } \\
\text { Disagree } 0(0 \%)\end{array}$ \\
\hline 4. & $\begin{array}{l}\text { Is awareness can affect success in the } \\
\text { implementation of IT governance? }\end{array}$ & $\begin{array}{l}\text { Strongly } \\
\text { Agree } 14(70 \%)\end{array}$ & $\begin{array}{l}\text { Agree } \\
6(30 \%)\end{array}$ & $\begin{array}{l}\text { Undecided } \\
0(0 \%)\end{array}$ & $\begin{array}{l}\text { Disagree } \\
0(0 \%)\end{array}$ & $\begin{array}{l}\text { Strongly } \\
\text { Disagree } 0(0 \%)\end{array}$ \\
\hline 5. & $\begin{array}{l}\text { Can awareness affect the failure of the } \\
\text { implementation of IT Governance? }\end{array}$ & $\begin{array}{l}\text { Strongly } \\
\text { Agree } 9(45 \%)\end{array}$ & $\begin{array}{l}\text { Agree } \\
4(20 \%)\end{array}$ & $\begin{array}{l}\text { Undecided } \\
1(5 \%)\end{array}$ & $\begin{array}{l}\text { Disagree } \\
5(25 \%)\end{array}$ & $\begin{array}{l}\text { Strongly } \\
\text { Disagree } 1(5 \%)\end{array}$ \\
\hline 6. & $\begin{array}{l}\text { How important is the role of awareness in } \\
\text { the implementation of IT Governance? }\end{array}$ & $\begin{array}{l}\text { Very Important } \\
16(80 \%)\end{array}$ & $\begin{array}{l}\text { Important } \\
4(20 \%)\end{array}$ & $\begin{array}{l}\text { Undecided } \\
0(0 \%)\end{array}$ & $\begin{array}{l}\text { Not Important } \\
0(0 \%)\end{array}$ & $\begin{array}{l}\text { Very } \\
\text { Unimportant } \\
0(0 \%)\end{array}$ \\
\hline 7. & $\begin{array}{l}\text { In your opinion, what factors are related to } \\
\text { awareness, so that it can affect the success in } \\
\text { implementing IT Governance? Please mention! }\end{array}$ & Frequency & & & Percentage & \\
\hline & Understanding & 9 & & & 21 & \\
\hline & Risk & 2 & & & 5 & \\
\hline & IT Resource & 1 & & & 2 & \\
\hline & Budget & 3 & & & 7 & \\
\hline & Stakeholder involvement & 4 & & & 10 & \\
\hline & Communication & 3 & & & 7 & \\
\hline & Policy & 3 & & & 7 & \\
\hline & Socialization & 2 & & & 5 & \\
\hline & Political & 3 & & & 7 & \\
\hline & Business Perspective & 2 & & & 5 & \\
\hline & Organizational culture & 4 & & & 10 & \\
\hline & Commitment & 1 & & & 2 & \\
\hline & User Profile & 2 & & & 5 & \\
\hline & Competence & 2 & & & 5 & \\
\hline & Consistency & 1 & & & 2 & \\
\hline
\end{tabular}


Figure 1 shows that almost all organizations stated that IT Governance has an important role in supporting the routine activities of an organization. A $90 \%$ value is a very meaningful and it means that IT Governance cannot be underestimated or simply ignored because it is very supportive in the survival of an organization. Figure 2 shows that the implementation of IT Governance tends to not always experience success and this is answered by almost half of the respondents (60\%). Only a small percentage agreed $(30 \%)$ that the implementation of IT Governance could experience success.

In Fig. 3 it can be seen that almost all respondents $(80 \%)$ stated that the implementation of IT Governance could experience a failure. This means giving a sign that is very important to be careful in implementing IT Governance. Preparation, planning and a good understanding of IT Governance seems to be an important note so that implementation can experience success. Figure 4 shows that awareness turns out to have an important influence on the implementation of IT Governance. Almost all agree (100\%) on this, therefore, awareness becomes an important note to be made special attention in order to have a serious attention for all parties involved without exception.

In addition to having an influence on the successful implementation of IT Governance, Awareness also has a high influence on failure in the implementation of IT Governance. Therefore, awareness needs to be raised for all parties involved, so the implementation of IT Governance does not experience a failure, this is shown in Fig. 5, i.e., the total number of respondents agreed and strongly agreed at $65 \%$. Figure 6 shows how important awareness has an impact on the implementation of IT governance. From the survey results stated that all respondents $(100 \%)$ gave answers that awareness had a very important influence in the implementation of IT Governance. This very important influence can be related to success or even vice versa. Therefore, as stated in previous statements, Awareness should not be underestimated or ignored in the implementation of IT Governance. Awareness needs to get a special place and need to get very serious attention.

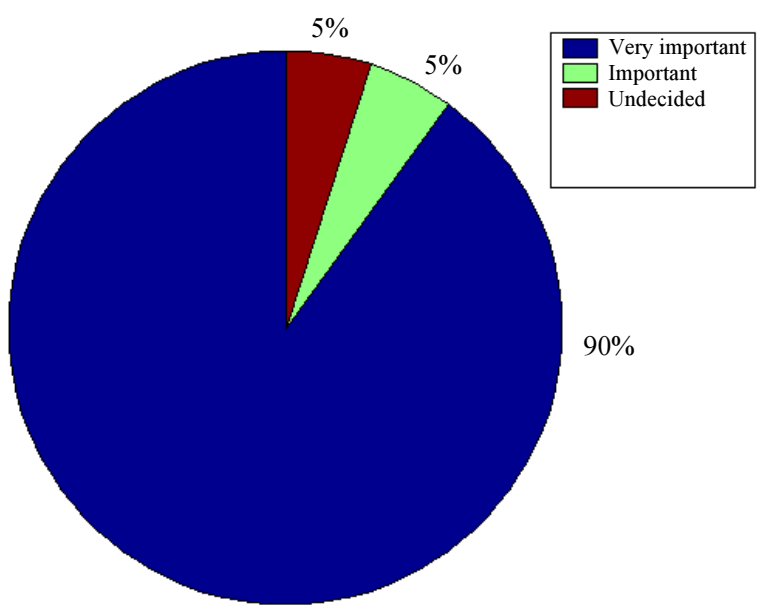

Fig. 1: Data showing the role of IT Governance in supporting organizational activities

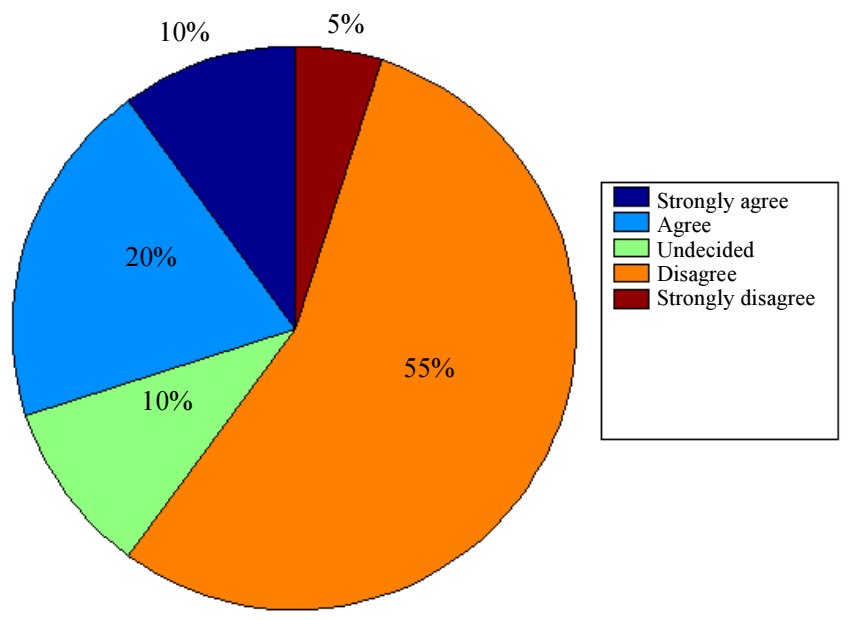

Fig. 2: Data that informs the implementation of IT Governance is likely to achieve success 


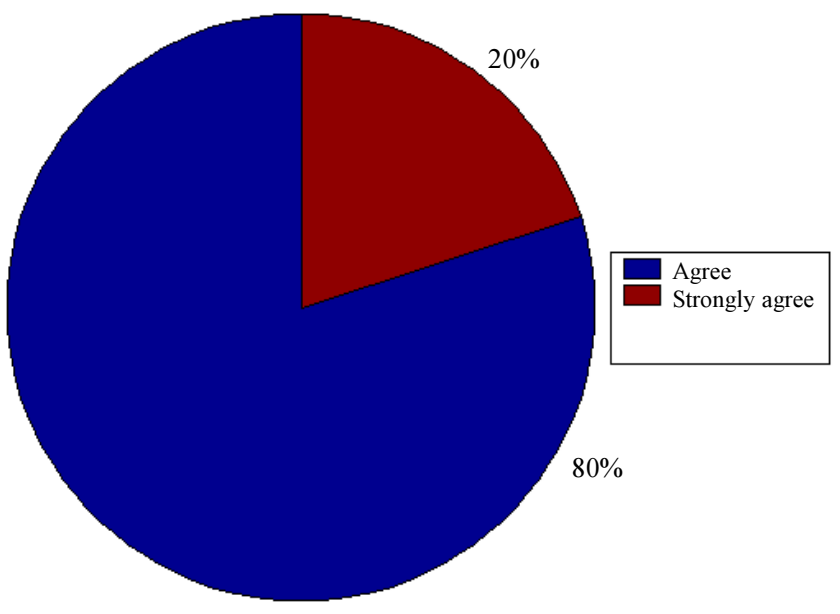

Fig. 3: Data that informs the implementation of IT Governance has a chance of failure

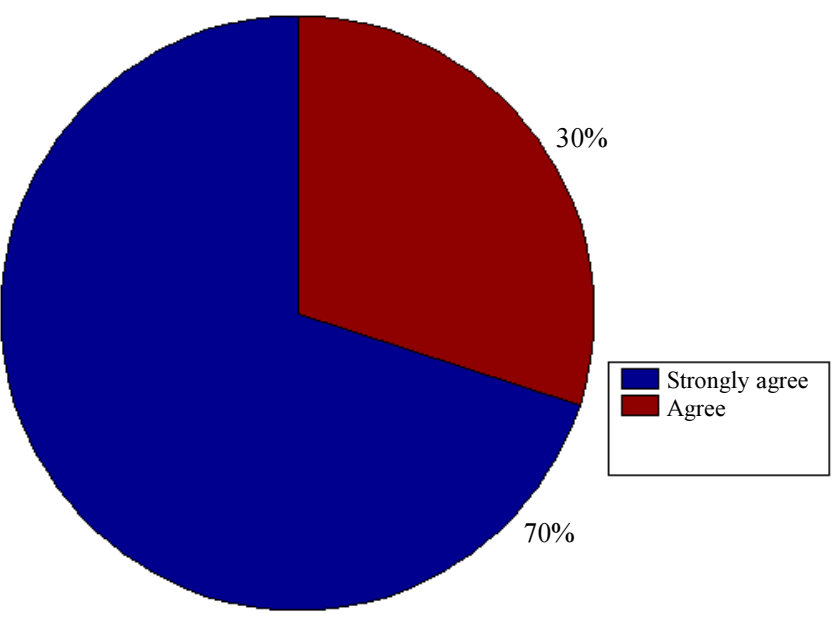

Fig. 4: Data that inform awareness can influence the success in implementing IT Governance

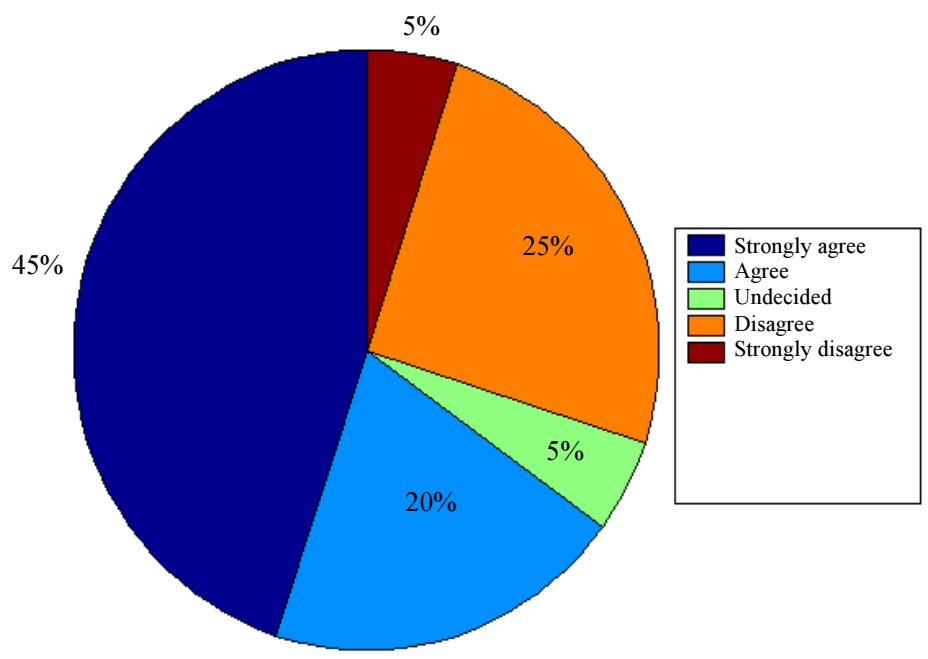

Fig. 5: Data that inform awareness can influence the failure in implementing IT Governance 


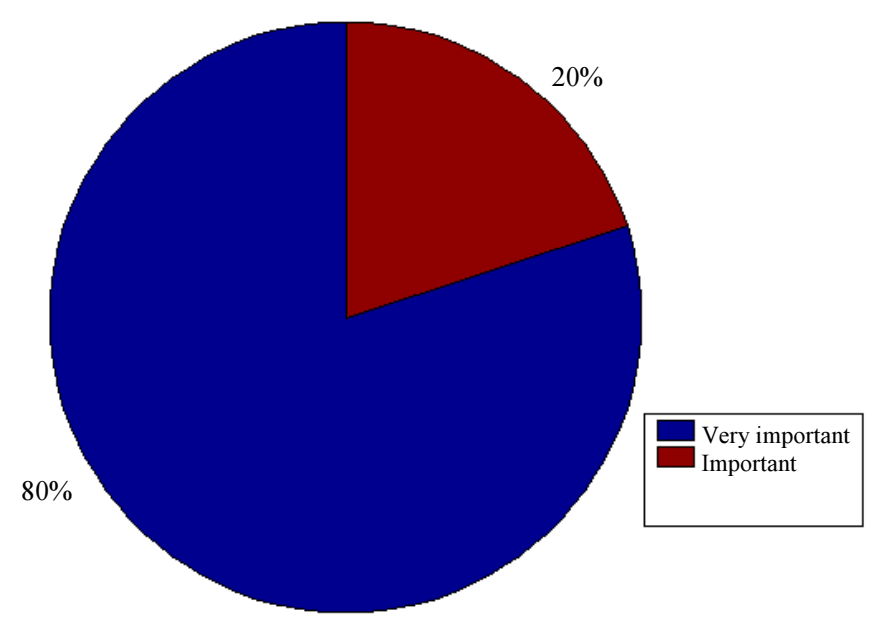

Fig. 6: The data confirms that awareness plays an important role in the implementation of IT Governance

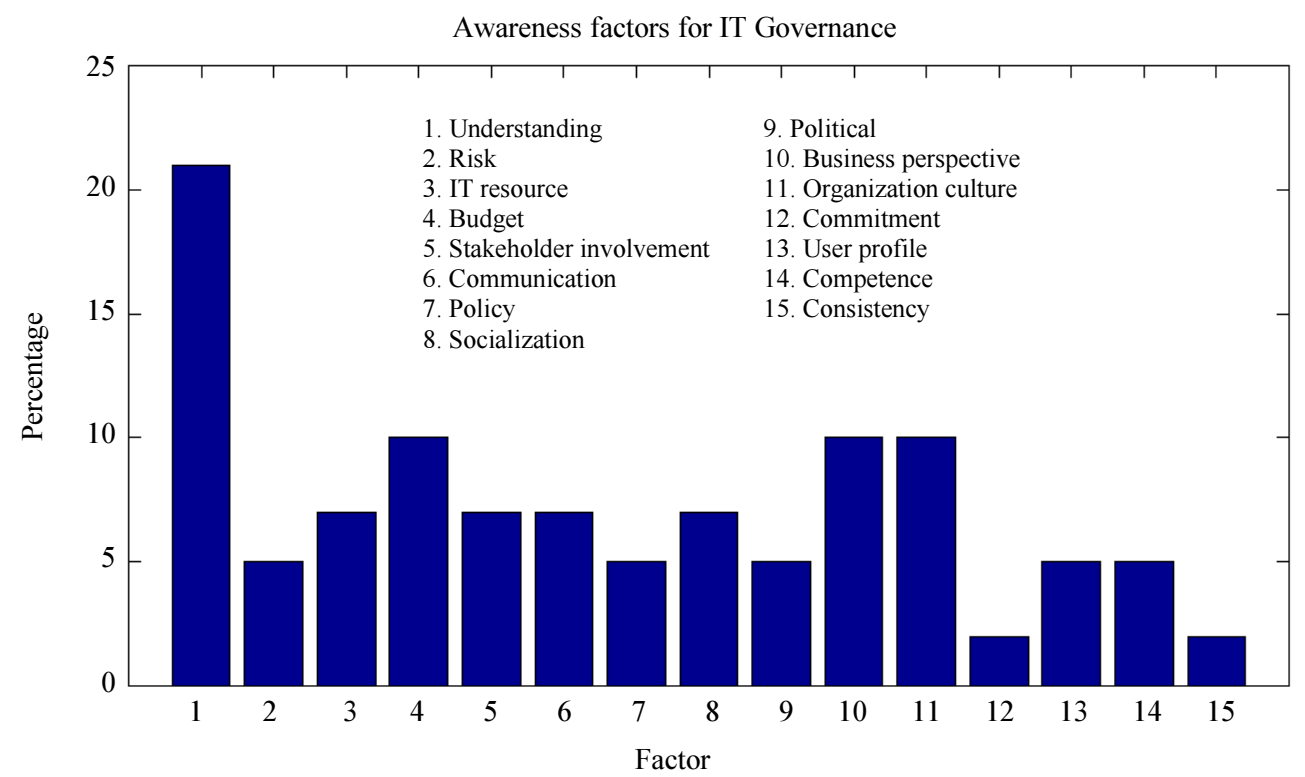

Fig. 7: Data on awareness factors according to respondents' opinions

The results of a survey involving respondents from IT Governance Experts in Indonesia stated that the implementation of IT Governance does not always experience success and results have been obtained showing that IT Governance has an important role in supporting the company's routine activities. In addition, the survey results also informed that awareness has an important role in the successful implementation of IT Governance.

Figure 7 is the result of the opinions of experts who in this study serve as respondents to provide input on what factors are related to the awareness that has an important influence on the implementation of IT
Governance. These emerging factors are the result of the accumulation and collectivity of thoughts from experts who can be used as valuable input and consideration, both for users, practitioners and researchers, especially in the field of IT Governance.

The interesting thing from the data above is that the understanding factor has the highest number of percentages among other factors $(21 \%)$, this shows that understanding is the most important thing and very significant in the implementation of IT Governance. This understanding factor contains meaning related to understanding the theories and concepts about IT Governance properly. This is very reasonable, if the 
understanding is good then it will also be good in its application and vice versa.

Not all IT governance implementations can experience success as expected. Failure in implementation is caused by a lack of awareness of all parties involved, especially from stakeholders. Awareness is soft IT Governance that is more focused on human behavior (Smits, 2018). Therefore, awareness is an important factor that has a major influence on the success in implementing IT Governance. Consciousness consists of several factors namely: Understanding, Risk, IT Resource, Budget, Stakeholder involvement, Communication, Policy, Socialization, Politic, Business Perspective, Organizational culture, Commitment, User Profile, Competence, Consistency, all of which need to get serious attention so that the implementation of IT Governance can experience success in the future.

The results of this study are very different from the results of research conducted by previous researchers. The interesting thing and a big contribution from the results of this study is that we have found important factors related to consciousness, which are obtained through the opinions of experts directly, where the important these factors are very closely related to human behavior, which significantly has an influence is very big in supporting successful implementation of IT Governance. Therefore, the results of this research that has been carried out have a great contribution in providing new references and knowledge in the field of IT Governance. Especially; soft IT Governance, which so far has not received attention from researchers and practitioners.

\section{Conclusion}

From the results of this study, it can be concluded that most experts argue that awareness has a major influence on the success in implementing IT Governance. Therefore, awareness is an important factor that must get serious attention so that the implementation of IT Governance can experience success. The experts also gave their opinion that awareness includes several factors including Understanding, Risk, IT Resource, Budget, Stakeholder involvement, Communication, Policy, Socialization, Politic, Business Perspective, Organizational culture, Commitment, User Profile, Competence and Consistency. Of these factors, if well understood and implemented consistently and then the implementation of IT Governance can experience success.

\section{Implications from the Study}

The implications of the results of this study are that it can provide insight and reference for stakeholders, especially for top-level management, namely, the board of directors and executive managers, related to the awareness factors that have been found. If the awareness factors that have been found are well understood and implemented consistently, then the implementation of IT governance can experience success so that the organization's goals can be achieved, namely the alignment between business and IT.

\section{Research Future}

From the whole of these awareness factors that have been found, the hopes can be utilized as optimally as possible and can be further developed so that in the future the implementation of IT Governance can experience success as expected.

This research is still far from perfection because it has many limitations including the issue of time and cost, where we cannot involve many experts and conduct more in-depth interviews so that we have not had the chance to get a more detailed explanation of each factor of awareness.

Therefore, future research is suggested to examine and analyze further from the factors that have been found, related to awareness factors in the implementation of IT Governance, namely by looking for sub-factors of each of these factors, so that this study becomes more complete and meaningful.

\section{Acknowledgement}

The author would like to thank the friends of Doctoral Program of the Computer Science University of Indonesia force 2016 for their support so that this survey can be completed well and smoothly as expected. This survey is a Thesis Grant for the doctoral student of the University of Indonesia with the number: 1562/UN2.R3.1/PPM.00.01/2018.

\section{Author's Contributions}

Bobby A.A Nazief: Selected the topic and analyzed the literature along with proposing and implementing the methods.

Uky Yudatama: Coordinated the data-analysis and contributed to the review of the manuscript.

Achmad Nizar Hidayanto: Supervising the research by reviewing the manuscript iteratively and giving suggestions and recommendations.

\section{Ethics}

This article is original and contains unpublished material. The corresponding author confirms that all of the other authors have read and approved the manuscript and no ethical issues involved. 


\section{References}

Al Qassimi, N. and L. Rusu, 2015. IT governance in a public organization in a developing country: A case study of a governmental organization. Proc. Comput. Sci., 64: 450-456.

Ali, S. and P. Green, 2012. Effective Information Technology (IT) governance mechanisms: An IT outsourcing perspective. Inform. Syst. Front., 14: 179-193. DOI: 10.1007/s10796-009-9183-y

Alreemy, Z., V. Chang, R. Walters and G. Wills, 2016. Critical Success Factors (CSFs) for Information Technology Governance (ITG). Int. J. Inform. Manage., 36: 907-916.

DOI: 10.1016/j.ijinfomgt.2016.05.017

Altemimi, M.A.H. and M.S. Zakaria, 2016. Developing factors for effective IT governance mechanism. Proceedings of the 9th Malaysian Software Engineering Conference, Dec. 16-17, IEEE Xplore Press, Kuala Lumpur, Malaysia, pp: 245-251. DOI: 10.1109/MySEC.2015.7475228

Aoun, C., S. Vatanasakdakul and Y. Chen, 2011. IT Governance Framework Adoption: Establishing Success Factors. In: Governance and Sustainability in Information Systems, Nüttgens, M., A. Gadatsch, K. Kautz, I. Schirmer and N. Blinn (Eds.), Springer Berlin Heidelberg, pp: 239-248.

Bianchi, I.S. and R.D. Sousa, 2016. IT governance mechanisms in higher education. Proc. Comput. Sci., 100: 941-946. DOI: 10.1016/j.procs.2016.09.253

Da Veiga, A. and J.H.P. Eloff, 2007. An information security governance framework. Inform. Syst. Manage., 24: 361-372.

DOI: $10.1080 / 10580530701586136$

De Haes, S. and W. Van Grembergen, 2008. Analysing the relationship between IT governance and business/IT alignment maturity. Proceedings of the 41st Annual Hawaii International Conference on System Sciences, Jan. 7-10, IEEE Xplore Press, Waikoloa, HI, USA. DOI: 10.1109/HICSS.2008.66

De Haes, S., T. Huygh and A. Joshi, 2017. Exploring the contemporary state of information technology governance transparency in Belgian firms. Inform. Syst. Manage., 34: 20-37.

DOI: $10.1080 / 10580530.2017 .1254444$

Desa, A., N.B.A. Kadir and F. Yusooff, 2011. A study on the knowledge, attitudes, awareness status and behaviour concerning solid waste management. Proc. Soc. Behav. Sci., 18: 643-648. DOI: $10.1016 /$ j.sbspro.2011.05.095

Hardy, G., 2006. Using IT governance and COBIT to deliver value with IT and respond to legal, regulatory and compliance challenges. Inform. Security Technical Rep., 11: 55-61. DOI: 10.1016/j.istr.2005.12.004
Ishak, S. and N.F.M. Zabil, 2012. Impact of consumer awareness and knowledge to consumer effective behavior. Asian Soc. Sci., 8: 108-114. DOI: $10.5539 /$ ass.v8n13p108

Kuusk, A. and J. Gao, 2015. Factors for successfully integrating operational and information technologies. Proceedings of the Portland International Conference on Management of Engineering and Technology, Aug. 2-6, IEEE Xplore Press, Portland, OR, USA, pp: 1513-1523. DOI: 10.1109/PICMET.2015.7273136

Lee, C.H., J.H. Lee, J.S. Park and K.Y. Jeong, 2008. A study of the causal relationship between IT governance inhibitors and its success in Korea enterprises. Proceedings of the Annual Hawaii International Conference on System Sciences, Jan. 7-10, IEEE Xplore Press, Waikoloa, HI, USA. DOI: $10.1109 / \mathrm{HICSS} .2008 .38$

Smits, 2018. The continuing mismatch between IT governance maturity theory and practice: A new approach. Proc. Comput. Sci., 138: 549-560. DOI: $10.1016 /$ j.procs.2018.10.075

Teo, W.L., A.A. Manaf and P.L.F. Choong, 2013. Information technology governance: Applying the theory of planned behaviour. J. Organiz. Manage. Stud. DOI: 10.5171/2013. 827871

Usta, K., 2019. Interpretive structural analysis for industry 4.0 adoption challenges. IEEE Trans. Eng. Manage. DOI: 10.1109/TEM.2018.2890443

Van Grembergen, W., 2006. IT governance and its mechanisms. Proceedings of the Annual Hawaii International Conference on System Sciences, (CSS' 06), pp: 193-193.

Xiang, W., Y. Li and Y. Shou, 2014. An empirical study of critical success factors of project governance in China. Proceedings of the IEEE International Conference on Industrial Engineering and Engineering Management, Dec. 10-13, IEEE Xplore Press, Bangkok, Thailand, pp: 405-409. DOI: 10.1109/IEEM.2013.6962443

Yadav, D.K. and A. Barve, 2015. Analysis of critical success factors of humanitarian supply chain: An application of interpretive structural modeling. Int. J. Disaster Risk Reduct., 12: 213-225. DOI: 10.1016/j.ijdrr.2015.01.008

Yang, S., S. Zhang and L. Kong, 2012. Research on the cooperative decision of business application needs in IT governance. Proceedings of the IEEE 16th International Conference on Computer Supported Cooperative Work in Design, May 23-25, IEEE Xplore Preass, Wuhan, China, pp: 268-273. DOI: 10.1109/CSCWD.2012.6221829 
Yudatama, U. and R. Sarno, 2015. Evaluation maturity index and risk management for it governance using fuzzy AHP and fuzzy TOPSIS (case study bank XYZ). Proceedings of the International Seminar on Intelligent Technology and its Applications, May 20-21, IEEE Xplore Press, Surabaya, Indonesia, pp: 323-327. DOI: 10.1109/ISITIA.2015.7220000

Yudatama, U., A.N. Hidayanto and B. Nazief, 2017. Awareness and attitudes toward it governance: Empirical study. J. Theoretical Applied Inform. Technol., 95: 2680-2687.
Yudatama, U., A.N. Hidayanto and B. Nazief, 2018a. Approach using Interpretive Structural Model (ISM) to determine key sub-factors at factors: Benefits, risk reductions, opportunities and obstacles in IT governance awareness. J. Theoretical Applied Inform. Technol., 96: 5537-5549.

Yudatama, U., A.N. Hidayanto and B. Nazief, 2018b. Documents and IT resources as essential element in awareness IT governance: An analysis of study. J. Theoretical Applied Inform. Technol., 96: 5889-5904. 